\author{
Suraj Wasudeo Nagre* \\ Department of CVTS, Grant Medical College, \\ Mumbai, India
}

Dates: Received: 16 August, 2016; Accepted: 29 August, 2016; Published: 30 August, 2016

*Corresponding author: Dr Suraj Wasudeo Nagre, MBBS, MS, M.Ch, CVTS, DNB, CVTS, Associate Professor, Department of CVTS, Grant Medical College, 31, Trimurti Building, J J Hospital compound, Byculla, Mumbai, India, Mobile no -09967795303;

E-mail - surajnagre@yahoo.com

www.peertechz.com

ISSN: 2455-2976

Keywords: Aortic valve; Ministernotomy; CPB (cardiopulmonary bypass); VR (aortic valve replacement)

\author{
Research Article
}

\section{Hurdles for Starting Ministernotomy Aortic Valve Replacement Program}

\section{Introduction}

In this era of percutaneous interventions and minimal invasive surgery, ministernotomy aortic valve replacement is good option to start minimal invasive cardiac surgery in any institute. Aortic valve replacement seems more feasible through ministernotomy as aorta is anterior structure and cannulation required can be done through exposed aorta and right atrium [1]. Most importantly it can be done with same intruments that are used in conventional full sternotomy aortic valve replacement. Patients with same criteria (Table 1), are selected and divided into two groups. In Group one 10 cases undergone ministernotomy AVR anvd in Group two 10 cases undergone conventional full sternotomy AVR .Observations in both groups are compared.

\section{Patients and Methods}

Twenty patients of aortic valve replacement surgery - ten by ministernotomy and ten by full sternotomy studied at our institution Grant Medical College, Mumbai from May 2013 to May 2016.

Table 1: Patient Selection Criteria In Group 1 and Group 2.

\begin{tabular}{|l|l|}
\hline \multicolumn{1}{|c|}{ Selection Criteria } & \\
\hline Male/Female & $6 / 4$ \\
\hline Age Group & $20-40$ years \\
\hline Aortic Annulus & $20-22 \mathrm{~mm}$ \\
\hline Regurgitant/Stenotic lesion & $7 / 3$ \\
\hline Pathology & Rheumatic $7 /$ Bicuspid 3 \\
\hline
\end{tabular}

In both groups, techniques used for heparinisation, cannulation (Figure 1), going on bypass, aortic valve excision (Figure 2a,b), mechanical valve used, suturing technique (pledgetted ethibond with pledget on left ventricle side), all are same. Intraopt and postopt observations in both groups are compared.

\section{Intraopt observation}

\begin{tabular}{|l|l|l|}
\hline & Ministernotomy AVR & Full sternotomy AVR \\
\hline Sternotomy to cross clamp time & 30 minutes[20-40] & 30 minutes[20-40] \\
\hline Total cross clamp time & 60 minutes[40-90] & 60 minutes[40-90] \\
\hline Closure time & 25 minutes[20-40] & 30 minutes[20-40] \\
\hline
\end{tabular}

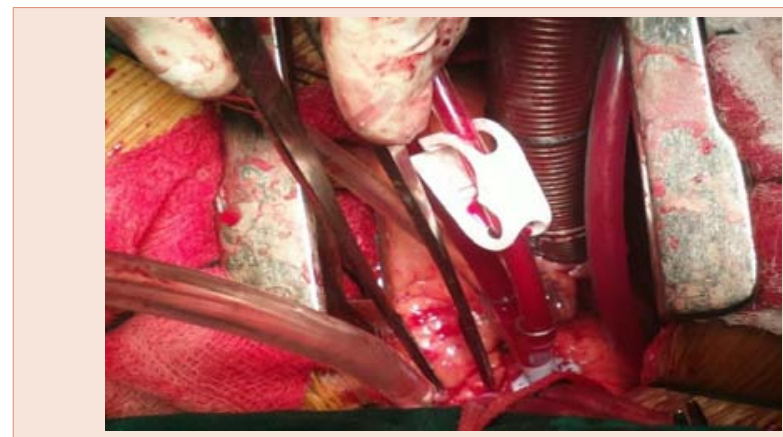

Figure 1: All canulations as routine. Arterial aortic cannula, venous dual stage cannula in right atrial appendage and cardioplegia cannula in ascending aorta.

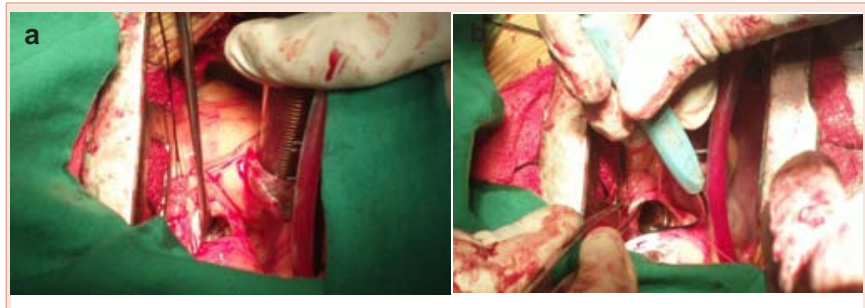

Figure 2: a). Adequate aortic valve exposure. b). No difficulty in sizing the aortic annulus. 


\section{Postopt observation}

$\checkmark$ Single pericardial drain was placed which was removed after 48 hours and incision size was $5 \mathrm{~cm}$ only (Figure $3 \mathrm{a}, \mathrm{b}$ ).

$\checkmark$ Less pain [pain score reduced to 6]

Early mobilisation and discharge from hospital.

$\checkmark$ No reexploration.

Deoperation required in one patient due to significant paravalvular leak cause may be defective surgical technique.

$>$ No Mortality.

\section{Comparision $[2,3]$}

- Sternotomy time was more in initial cases of ministernotomy group but it decreased with experience.

$\checkmark \mathrm{CPB}$ time, cross clamp time, CCU stay was same as compared to full sternotomy AVR patients.

D Ministernotomy incision was cosmatically superior and without any complications as compared to full sternotomy incision.

$\Delta$ Pain was less in ministernotomy group.

\section{Discussion}

Starting ministernotomy aortic valve replacement program was challenging. What Hurdles we faced and techniques to overcome them are discussed here

\section{Sternotomy}

Initial cases it was slightly difficult and time consuming to do ministernotomy but with time and experience duration became less. For easy access to right atrial appendage and for insertion of vent through LA-RSPV junction, we preferred right side ministernotomy that is J shaped rather than $L$ shaped. It was preferable to keep the saw side by in sterile tray after ministernotomy so that in emergency if full sternotomy required can be done easily [4].

First the suprasternal notch and xiphoid are marked and then 2 $\mathrm{cm}$ below suprasternal notch manubriosternal joint was marked $.5 \mathrm{~cm}$ incision was taken starting from manubriosternal joint (Figure 4) towards xiphoid.

\section{Pursestring and suturing}

It was preferable to take pursestring by open hand grip method of holding the needle holder (Figure 5). It allows use of minimum space without any difficulty.

\section{Deairing}

Difficulty in deairing because of limited exposure and enlarged left ventricle. It overcome by giving hot shot and deairing through left atrium roof and appendage by direct needle aspiration. It can be overcome by use of carbondioxide insufflation if available. Transesophageal echocardiography was useful for complete deairing.

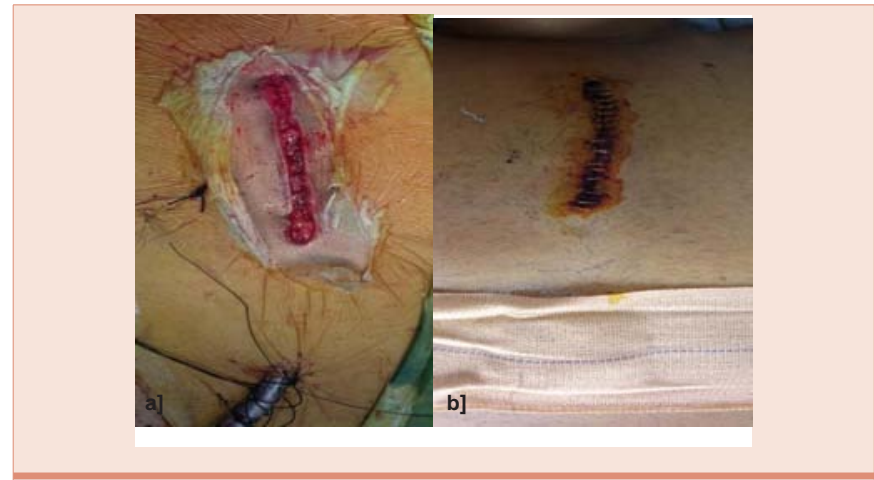

Figure 3: a). Single pericardial drain b) $5 \mathrm{~cm}$ incision site

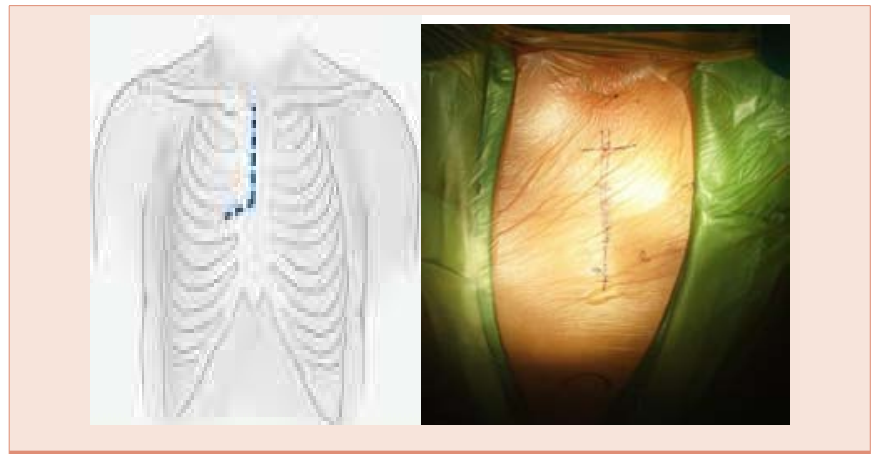

Figure 4: Incision and sternotomy.

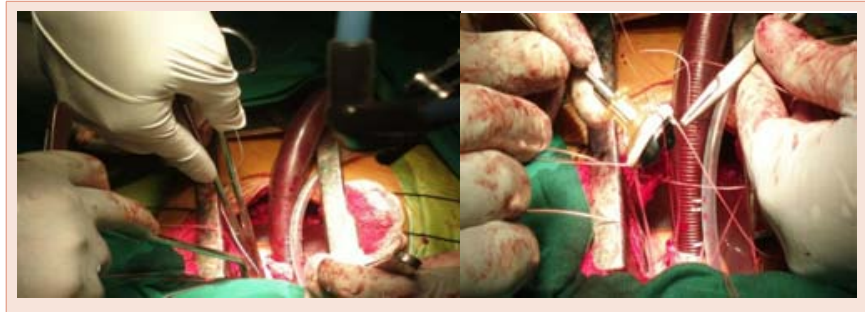

Figure 5: Open hand grip technique for suturing

\section{Massaging}

Proper cardiac massage was difficult due to limited exposure and enlarged left ventricle. As a result heart tends to fill with blood and become distended causing subendocardial ischemia hampering the myocardial protection.

\section{Shock delievery}

Due to difficulty in deairing and massaging, heart tend to fibrillate and even by using peadiatric shock paddles it was not possible to reach left ventricle through ministernotomy route. Two of our first patients required conversion to full sternotomy for same. Use of disposable external shock paddles (Figure 6) become important prerequisite for ministernotomy surgeries.

Advantages of ministernotomy aortic valve replacement

Without increase in operative time, ministernotomy provides adequate exposure, good cosmesis and less pain. Main hurdle 


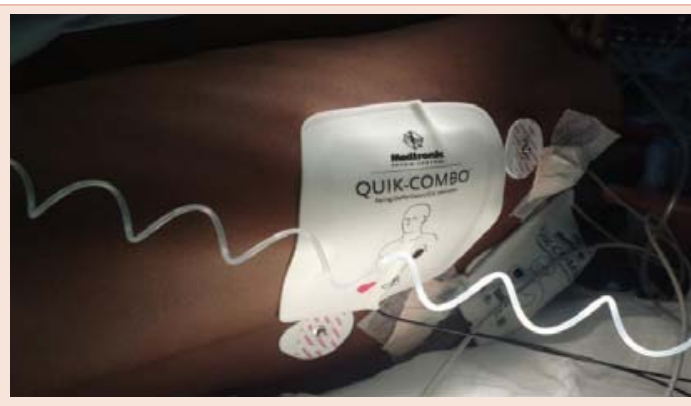

Figure 6: Disposable external shock paddles on back.

encountered was while delivering shock when heart was fibrillating and overcame by using disposable external shock paddles. It preserves respiratory mechanics. Cost savings as no new equipment was required. Early mobilization and reduced hospital stay. Ease of conversion to full sternotomy. Redosternotomy becomes easier $[5,6]$

Postopt 2 D Echo of first ministernotomy AVR patient showed significant paravalvular leak due to surgical technique problem requiring reoperation within 20 days.

Disadvantages of ministernotomy aortic valve replacement

Inability to visualize whole heart. Difficulty in deairing the heart. Difficulty in applying the epicardial pacing wires so it is better to apply when patient is on CPB. Limited control in case of heamorrhge. Steep learning curve.

\section{Conclusion}

Disposable external shock paddles and transesophageal echocardiography is must. Ministernotomy AVR though technically challenging but with increased surgical experience, it offer results comparable to the conventional full sternotomy AVR. Ministernotomy
AVR will always maintain its place in between full sternotomy AVR and minithoracotomy AVR. Even with early difficulties and operative hurdles we continued our efforts to improve and succeeded in it.

\section{Limitation of our study}

$\Delta$ Number of cases studied are small.

D Patients above forty years of age are not in study.

D Degenerative and calcific aorta are get excluded from study.

\section{Ethical Approval}

All procedures performed in studies involving human participants were in accordance with the ethical standards of the institutional and/or national research committee and with the 1964 Helsinki declaration and its later amendments or comparable ethical standards.

\section{References}

1. Benetti FJ, Mariani MA, Rizzardi JL, Benetti I (1997) Minimally invasive aortic valve replacement. J Thorac Cardiovasc Surg 113: 806-807.

2. Liu J, Sidiropoulos A, Konertz W (1999) Minimally invasive aortic valve replacement (AVR) compared to standard AVR. Eur J Cardiothorac Surg 16: S80-83.

3. Detter C, Deuse T, Boehm DH, Reichenspurner H, Reichart B (2002) Midterm results and quality of life after minimally invasive vs. conventional aortic valve replacement. Thorac Cardiovasc Surg 50: 337-341.

4. Svensson LG, D’Agostino RS (1998) “J” incision minimal-access valve operations. Ann Thorac Surg 66: 1110-1112.

5. Tabata M, Khalpey Z, Shekar PS, Cohn LH (2008) Reoperative minimal access aortic valve surgery: minimal mediastinal dissection and minimal injury risk. J Thorac Cardiovasc Surg 136: 1564-1568.

6. Byrne JG, Aranki SF, Couper GS, et al. (1999) Reoperative aortic valve replacement: partial upper hemisternotomy versus conventional full sternotomy. J Thorac Cardiovasc Surg 118: 991-997. 